FACTA UNIVERSITATIS

Series: Economics and Organization Vol. 16, $\mathrm{N}^{\mathrm{o}} 1$, 2019, pp. $31-47$

https://doi.org/10.22190/FUEO1901031A

Original Scientific Paper

\title{
COMPENSATION MANAGEMENT AND EMPLOYEES' MOTIVATION IN THE INSURANCE SECTOR: EVIDENCE FROM NIGERIA
}

\author{
UDC 347.426.6:005
}

\begin{abstract}
Abayomi Olarewaju Adeoye
Department of Business Administration, Lagos State University, Lagos, Nigeria
\end{abstract}

\begin{abstract}
Reimbursement has been one of the frameworks adopted in organisations to attract, hire and keep competent employees that will strategically key in to the firm's vision, task and goals. Retaining skillful employees in officialdom is imperative for the progress and enrichment of general operation of a firm. Staff that is well motivated will strive to ensure that competitive advantage goal of the organisation is sustained and achieved over their competitors. The aim of this paper is to explore the association between compensation management and employees' motivation in the insurance sector of Nigeria. This study employed a non-experimental design using questionnaires as a measuring instrument to gather information. There were 250 questionnaires administered, 213 collected while 212 (84.4\%) thereof were found to be usable. By employing the Pearson product moment correlation coefficient, it was discovered that association exists between reward administration and workers' motivation but a weak one. It was revealed that in Nigeria insurance industry, compensation management bears a minimal influence on the enthusiasm of workers'. It is hence recommended that remuneration package of employees' in the insurance industry in Nigeria should be given priority by carrying out periodic review of the salary and making it at par with other industries in the financial sector of Nigeria.
\end{abstract}

Key words: compensation management, employees, insurance industry, motivation, Nigeria

JEL Classification: M52, M12

Received August 07, 2018 / Revised November 23, 2018 / Accepted January 15, 2019

Corresponding author: Adeoye Abayomi Olarewaju

Department of Business Administration, Lagos State University, Lagos, Nigeria

E-mail: abayomi.adeoye@lasu.edu.ng 


\section{INTRODUCTION}

It is essential that organisations formulate plans that facilitate achievement that will lead to best management practice, workers' improvement; increasing the cutting edge of both the firm and staff is also imperative for the correlation of human resource management (HRM) and the outcome of the firm. Across core functional areas of human resource practices such as recruitment, task evaluations, staff enhancement, manpower designing, workers' engagement, in addition to reward dispensation, affinity of remuneration and effort is a subject of concern in extant literatures. It is assumed that adequate reward system can motivate individuals to perform and therefore contribute positively to the firms' outcome (Al-Shaiba \& Koç, 2017; Tsai, 2005).

One of the functions of HRM is compensation management which entails benefits that individuals are receiving in exchange for the task performed within the establishment (Dessler, 2008; Khan, Aslam \& Lodhi, 2011; Nazim-ud-Din, 2013; Van der Merwe, 2009). Compensation is the cost of doing business for many organisations (Hackett \& McDermott, 1999; Ivancevich, 2004).

The issue of remuneration plays a vital role in decision making of new entrants and existing staff of the firm. It encourages organisations in implementing the style of the firm that enhances their aggressive gain against main rivals in the same line of operation (Heneman, Judge \& Heinemann, 2000; Hyondong, 2006; Ivancevich, 2004; Rotea, Logofatu $\&$ Ploscaru, 2018). Additionally, pecuniary funds are spent in fashioning, systematising and managing recompense arrangements within the company. Despite its contributions toward the success and business enlargement, academics and specialists argued that the progress of research investigation of reward strategies has been slow (Heneman et al., 2000; Kersley \& Forth, 2005). Recently, strategy of administering workers' emolument has taken a dramatic shift in nature. This is a demonstration of inducement factor on staff's outcome (Heneman et al., 2000; Purcell, Kinnie, \& Hutchinson, 2003).

Motivation simply means encouragement to act in a certain way, which may be negative or positive. It is one of the interesting terms in management literature. Motivation is described as one of the fundamental functions of a manager who is responsible for ensuring that the goals of the organisation are accomplished by boosting morale of employees. The word motivation was coined out of Latin word 'movere' signifying movement (Adeoye, 2014; Kreitner \& Kinicki, 1998). Motivation denotes 'those psychological processes that cause stimulation, guidance and endurance of voluntary actions that are goal oriented' (Mitchell, 1982). Motivation is said to be the propelling force supporting individual's action that boost goal comportment in order to fulfil some needs or expectation (Ahlstrom \& Bruton, 2010; Kelly, 2009; Seiler, Lent, Pinkowska, \& Pinazza, 2011). Ramlall, (2004: 52), Walker, Greene and Mansell (2006) alluded that motivation is the inclination to put up effort to accomplish structural targets, conditioned by the different types of motivation, namely: financial and non-financial motivation, intrinsic and extrinsic motivation.

This study aims to explore the association between reward administration and employees' motivation. We argue that compensation management influences employee's motivation through pay satisfaction, fair pay, overtime payment and adequate review of salary (Mckee-Ryan \& Harvey, 2011; Khoreva, 2012; Aguinis, Joo \& Gottfredson, 2013; Adeoye \& Fields, 2014; Kalshoven \& Boon, 2015; Kumar, Hossain \& Nasrin, 2015). 


\section{LITERATURE REVIEW}

A major function of compensation management is to modify the employee's behaviour and cause them to act in certain way. Though an organisation intends to encourage employees to stay within the organisation, it also strengthens employees' effort with adequate reward administration. Three major components in motivation are: what is crucial to the employee, trading it for something, then getting the needed behaviour (Milkovich \& Newman, 1999; Tang, Luna-Arocas, Sutarso, \& Tang., 2004). Hence, offer from the organisation influences an employee's behaviour through an exchange procedure.

\subsection{Compensation management}

Compensation management refers to the function of human resources management (HRM), which talks about the return individuals get for executing a task within the organisation. It is the cost of doing business for many organisations, that is, employees' trade labour and loyalty for financial and non- financial compensation related to wage, allowances, services, as well as recognition. It is also viewed as a propelling engine for employees' performance when institutions endeavour to make them better persons by adding to employees' satisfaction and development (Nzyoka \& Orwa, 2016; Mabaso \& Dlamini, 2017; Uwizeye \& Muryungi, 2017). Reward system is put in place to achieve fairness that is acceptable to both the employer and employees (Mujataba \& Shuaib, 2010; Agwu, 2013). The desired outcome of compensation management is to recruit employees who are enticed to work and encouraged to serve the employer, retain them, reduce labour turnover, absenteeism and thus reduce the potential for industrial conflict (Ivancevich, 2004; Nickels, McHugh, \& McHugh, 1999; Nikonova, Uspenskaya, Nazarova $\&$ Voikina, 2018). The major function of HRM relating to compensation encompasses managing financial participation such as save-as-you-earn (SAYE) schemes, Share Incentive Plans (SIPs) and worker's retirement and salaries. It also involves employee engagement, fair pay, executive reward, etc. (Chartered Institute of Personnel Development (CIPD), 2005 \& 2006).

Remuneration administration is strategic in nature especially in line with organisation's pursuit, vision and corporate goal, as well as supporting Human Resources Strategy (HRS) needs. Moreover, an organisation has numerous ways to connect its mission and values to a strategic business-driven payment philosophy. Compensation management is associated with better business performance and organisation should connect its mission and values to its compensation systems. There are different methods of determining workers' remuneration and these include job evaluation, merit pay, market surveys, the change in nature of pay as well as performance-based pay (Heneman, 2002).

\subsection{Objectives of compensation management}

The reimbursement function is aimed at grafting a system of incentives that is impartial and satisfactory to both parties in employment relationship. The consequential effect of reward is the attraction and encouragement of staff to provide a remarkable service for the employer. Nickels et al., (1999) and Ivancevich (2004) highlighted the objectives of compensation as follows: 
- Draw: Drawing the right kind of people that are having the prerequisite qualification and know-how needed by the organisation and in sufficient numbers.

- Justifiable: fairness should be employed in fixing the amount paid in line with work, capabilities, talents and education attained.

- Impartial: Emolument, returns and recompense should be comprehensive in nature.

- Protection: Assuring personnel' financial security such as insurance and retirement scheme.

- Reduced Expenses: The wage should not be bogus and be within what the organisation can afford.

- Inducement Offering: The remuneration must offer enticements that will stimulate well, competently and fruitfully at work.

- Holding: The earnings should hold back valued employees and discourage them from joining competitors or starting similar firms.

- Competitive Position: The pay should maintain a competitive advantage in the marketplace by maintaining low charges through high productivity from a satisfied labour force.

\subsection{Types of compensation}

\subsubsection{Financial compensation}

Financial compensation is also known as compensation in monetary terms, which comprises of financial rewards and financial incentives. According to Armstrong (2003: 687), 'monetary compensations offer financial recognition for outstanding achievements or recording high above targets or reaching certain levels of competence or expertise while economic spurs aims at motivating people in achieving goals, performance enhancement or improve their proficiency or proficiencies by focusing on specific targets and priorities'. This is a cost to the employers which acts as an antidote to the motivation of an employee that invariably transforms the performance of the employees' which also translates to positive organizational outcome (Idris, Hamzah Sudiirman \& Hamid, 2017, Mardiyanti, Utami \& Prasetya, 2018).

\subsubsection{Non- financial compensation}

This is a kind of compensation that does not involve money directly and this reward is normally intrinsic to the job: e.g. accomplishment, sovereignty, appreciation, the span to apply for skill improvement, and tuition and vocational openings (Armstrong 2003). This is made up of rewards that boost the employee's morale and are not costly to the employer (Danish \& Usman, 2010; Resurreccion, 2012; Whitehead \& Phippen, 2015, Oburu \& Atambo, 2016; Idris, Hamzah Sudiirman \& Hamid, 2017, Mardiyanti, Utami \& Prasetya, 2018).

\subsection{Variables relating to compensation}

The variables related to compensation are as follows: pay dissatisfaction, equitably underpaid, underpaid, overtime underpaid, inadequate review of salary and salary review not based on procedures. 


\subsubsection{Pay Dissatisfaction}

This occurs when employees perceive that what they earn does not match-up with their expectations, that is, when they think that the value of what they earn does not reflect the effort they actually put into their jobs. Hence, there is no motivation to execute their duties the way they ought to (Rynes, Gerhart \& Minette, 2004; Aguinis, Joo \& Gottfredson, 2013; Darma \& Supriyanto, 2017). Moreover, if there is a strong pay satisfaction, organisational commitment on the part of workers is increased and vice versa (Tang \& Chiu, 2004; Ali \& Panatik, 2015; Pepra-Mensah, Adjei \& Agyei, 2017).

\subsubsection{Equitably underpaid}

This exists when individuals perceive there is a difference in their jobs and outcomes compared to what they perceive to be the inputs or outcome of others (Adams, 1963; Leete, 2000; Yao, Locke \& Jamal, 2018). The relevant reference group is assumed to be other employees in the same occupation in the same firm, all employees in the same firm, workers in similar occupation in other firms, or other workers in other firms. The presence of the equitably underpaid will dampen the morale of employees' leading to dissatisfaction, hence, affecting the organisational performance and the performance of individual employees (Leete, 2000).

\subsubsection{Underpaid}

The concept of underpaid is when the employees perceive that their income and output do not match the perceived income and output of others. When there is underpayment, it results in greater pay dissatisfaction than when there is equity in compensation. Underpayment is perceived when there are discrepancies in pay despite the fact that employees put in the same effort (Sweeney, 1990; James \& Kim, 2018). Similarly, Brown (2001) likened underpayment to inequity. When workers perceive inequity in their salary in relation to others, it has a negative consequence on their productivity and that of the organisation. In addition, Maynard, Joseph and Maynard (2006) argue that underpayment is as a result of underemployment, which has a direct linkage to poor job satisfaction. Hence, motivation of the employees is reduced and invariably leads to intention to quit the job on the part of the employees.

\subsubsection{Overtime underpaid}

The issue of overtime payment is one of the pertinent factors in determining employees' motivation. This is part of the cash-based compensation that is adopted by organisation to motivate employees. Overtime is the allowance paid for extra time spent over and above the normal working hours. Overtime pay has played an important role in workers' satisfaction (Chiu, Luk \& Tang, 2002). The findings of this current study show that many insurance workers are dissatisfied because of the overtime underpayment by their organisation.

\subsubsection{Inadequate review of salary}

Review of salaries in organisations is one of the crucial factors used to motivate employees' towards the attainment of greater performance. Common practice is for the salary review to be anchored to promotion to the next level or cadre or an annual increment on the basic salary and may include other emoluments. The annual salary review is an ample opportunity to measure and quantify the performance and accomplishments of past effort 
within an accounting period. The review also creates an avenue to draft the next line of action or the objectives for the following year. Serhan, Achy and Nicolas (2018) acceded that adequate and effective review of salary will lead to employees' motivation in the public sector thereby enhancing high productivity. However, every set objective should be measurable and the mode of measurement should be quantitative in nature. The management should set targets that should carry an assigned value or weighting. Specifically, yearly targets or goals should carry numerical weightings and this will enable the employees' to understand their tasks with the aim of accomplishing them within a reasonable time frame (Swartz, 2006). The current study shows that salary review is not often done in insurance firms in Nigeria and employees' are not motivated or geared toward greater performance and in some cases the salary review is done downwardly.

\subsection{Motivation}

This is one of the fundamental functions that a manager performs to ascertain that the goals of the organisation are accomplished by boosting employee morale. As already mentioned, the word "motivation" was gotten from a 'movere', tantamount to motion (Kreitner \& Kinicki, 1998). Stimulus represents 'those emotional courses that triggers of deliberate engagements focused on a particular goal' (Herzberg, Mausner \& Snyderman, 1959, Mitchell, 1982, Lin, 2007; Woźniak, 2017). Motivation is described as a propeller for individual's actions for putting up certain behaviour to accomplish a purpose (Kelly, 2009, Ahlstrom \& Bruton, 2010; Olusadum \& Anulika, 2018).

Osterloh, Frost and Frey (2002) and Kuranchie-Mensah and Amponsah-Tawiah (2016) say that motivation comprises two dimensions, these being extrinsic and intrinsic in nature. Extrinsic motivation is when employee's satisfy their needs indirectly, especially through monetary or financial remuneration, while intrinsic motivation occurs when an activity achieves the immediate satisfaction of a worker's needs. Egan, Yang and Bartlett (2004) viewed motivation as a means of knowledge transfer which they described as the intention of the trainee to adopt the knowledge and skills acquired to improve and uplift the job when they are adequately remunerated. Adeoye (2001, p. 46) alluded that "motivation is a bait to stir the staff curiosity to accomplish a set up goal of an organisation'.

\subsubsection{Pecuniary motivation}

Pecuniary motivation is said to be straight or overt. Straight pecuniary motivation comprises reward of the employees like incomes, earnings, extras or commissions, while overt pecuniary motivation entails pecuniary motivation or booties that are not included in straight pecuniary motivation such as holiday, child welfare or senior citizen welfare care, various kinds of insurance, etc. (Ivancevich, 2004).

\subsubsection{Non- pecuniary motivation}

This non-pecuniary motivation has no monetary involvement, such as commendation, accountability, respect and appreciation that influences motivation and efficiency of staff (Ivancevich, 2004; Willis-Shattuk, Bidwell, Thomas, Wyness, Blaauw \& Ditlop, 2008; Meta, Alib \& Alic, 2015). 


\subsubsection{Intrinsic motivation}

Intrinsic motivation is derived by an employee from doing a job well, which also provides immediate satisfaction or fulfils a need that is enhanced by commitment to the work. Osterloh $(2005$, p. 8) argued that 'intrinsic motivation is enhanced by dedication to duty, according to the saying that if you want to encourage people to do a good job, assign a good job to them'. Lin $(2007$, p. 137) described intrinsic motivation as something 'that connotes pursuit for its own sake, passion, or for leisure and fulfilment stemmed from the experience'; while Gagne \& Deci (2005, p. 331) said 'intrinsic motivation enmeshes people engage in exploits because it is interesting and obtain unplanned gratification from the activity itself'. Osterloh and Frey (2000) looked at intrinsic motivation as carrying out a task for the provision of immediate needs and satisfaction. They concluded that the perfect incentive is embedded in the work making the staff satisfied and fulfilled.

\subsubsection{Extrinsic motivation}

This is how indirect wants are met, e.g. money as gratification for a well done task, e.g. salary adjustment, applause and advancement. As compensation, money is a means to an end, such as paying for a vacation or buying a car, and money is not an end in itself. For example, the job that one does is just a tool to satisfy one's needs using the salary paid for that job. Examples of extrinsic motivation as highlighted by Herzberg (1966) in his two-factor theory tagged hygiene factors are: salary, guardianship, social interactions, company policy and administration, working conditions and employment protection.

Osterloh and Frey (2000, p. 539) argued that "extrinsically staff is inspired when their needs are realised through pecuniary compensation'. Income offers fulfilment that is free of the real pursuit (Calder \& Staw, 1975, p. 599). Gagne and Deci (2005, p. 331) are of the opinion that "extrinsic motivation involves relationship concerning the pursuit and distinguishable outcomes like visible or voiced recompenses which leads to contentment from the extrinsic corollaries to which the activity leads. Extrinsic incentive targets result in details like encouragements obtained in the cause of carrying out an activity (Lin, 2007). Individual behaviour is geared to the perceived values and benefits that are attached to an action. Organisational rewards are a useful instrument to encourage individuals to perform in a desired way and they can take the form of financial inducements like salary review and leave allowances and non-financial incentives like career advancement and occupation protection (Lin, 2007; Nell, 2015).

\section{RESEARCH METHODS}

Quantitative research design was used for this study by distributing questionnaires. A predetermined set of questions was administered to a sample population to gather data for research questions to be addressed (Asika, 2008; Terre Blanche, Durrheim \& Painter, 2006; Saunders, Lewis \& Thornhill, 2013). Through the engagement of survey enquiry approaches, scholars adopt methods of inferential statistical tools that are applicable to assemble records (Baruch \& Holtom, 2008). From the population of this study, a selected sample was extricated. Quantitative survey design was engaged for the purpose of this study. Structured questionnaire was employed to elicit information from the respondents from a single insurance company. The data gathering from a single insurance company was due to many 
reasons suggested by Byron (2005) as lack of consistency can mar the study outcome and the interpretation problematic.

The data were gathered using the staff of one insurance enterprise situated in south-western part of Nigeria. Human Resources section of the insurance firm assisted in the distribution of the instruments to the staff. The management encouraged the employees to partake in the exercise fully. The privacy of the employees ascertained and maintained as completed questionnaires were returned to the HR department anonymously. In the study, 250 questionnaires were distributed, 213 were returned and 212 found usable and satisfactory representing 84.4\%. Two data collection instruments were employed for this study. Motivational Questionnaire published scale (MQS) by Mottaz (1985) was adapted, while the other one was self-developed.

Compensation management was rated employing a scale advanced by the researcher tagged Compensation Management Questionnaire Scale (CMQS) on a six-item measure to be responded to by the participants. The items used in this study include 'my salary is proportionate to my responsibility', 'my pay is greater than what parallel company pays' etc., and Likert's seven-point scale was used in measuring reactions of the respondents on 7 (strongly agree) to 1 (strongly disagree). In this study, the Cronbach's $\alpha$ was 0.87 which expresses internal consistency and reliability of the instrument.

The assessment of motivation was based on six-items imploring respondents to answer centred on Motivation Questionnaire Scale (MQS) Mottaz (1985), Brislin, Kabgting, Macnab, Zukies, and Worthly (2005), Mahaney and Lederer's (2006) and Altindis (2011). This is gauged on Likert five-point scale ranging from 1 (strongly disagree) to 5 (strongly agree). It is made up of 16 items and two dimensional scales; intrinsic motivation (IM) was appraised based on eight elements, illustrated by 'I do take responsibilities related to my work', while extrinsic motivation (EM) assessed engaging eight items, e.g. 'My promotional prospects are high'. For this study, IM Cronbach's $\alpha=.79$, IM Cronbach's $\alpha=.54$ and Motivation Cronbach's $\alpha=.90$ which reveals the reliability of the scales (Altindis). In this study, Likert's seven-point scale was employed ranging from 7 (strongly agree) to 1 (strongly disagree). Current Cronbach's $\alpha$ coefficient is 0.81 depicting internal consistency and reliability of the instrument.

Test of data reliability and consistency was done by calculating Cronbach alpha. Cronbach alpha coefficients $(\alpha)$ of the study were $\alpha=.869$ (for compensation management) and $\alpha=.813$ for (motivation). The generally accepted cut off is that the alpha scores should be higher than 0.70 (George \& Mallery, 2003). The entire Cronbach alpha depicts core stability and dependability of the data and questionnaire authenticity was done through experts in the field. The data collected could, therefore, be regarded as reliable and valid.

\section{RESULTS AND DISCUSSION}

The data analysis was done using descriptive and inferential statistics. The data was coded and grouped before inputting the result using the computer. The data collected were analysed and this was accomplished with the aid of Statistical Package for Social Sciences (SPSS) version 21. The choice of the package was predicated on its convenience in analysing and interpreting data (Muijs, 2011; Parke, 2013). The demographic profiles of the participants were explained via descriptive statistics while the study preposition was tested using Pearson product moment correlation. 
Compensation Management and Employees' Motivation in the Insurance Sector: Evidence from Nigeria 39

Table 1 Participant Biographical Characteristics

\begin{tabular}{|c|c|c|c|}
\hline Variable & Characteristics & Frequency & Percentage \\
\hline \multirow[t]{2}{*}{ Sex } & Men & 122 & $57.5 \%$ \\
\hline & Women & 90 & $42.5 \%$ \\
\hline \multirow[t]{6}{*}{ Conjugal Category } & Single & 75 & $35.4 \%$ \\
\hline & Married & 120 & $56.6 \%$ \\
\hline & Divorced & 7 & $3.3 \%$ \\
\hline & Widowed & 5 & $2.4 \%$ \\
\hline & Separated & 3 & $1.4 \%$ \\
\hline & Missing Item & 1 & $0.9 \%$ \\
\hline \multirow[t]{5}{*}{ Age } & 20-30 years & 59 & $27.8 \%$ \\
\hline & $31-40$ years & 92 & $43.4 \%$ \\
\hline & 41-50 years & 45 & $21.2 \%$ \\
\hline & 51 years or more & 15 & $7.1 \%$ \\
\hline & Missing Item & 1 & $0.5 \%$ \\
\hline \multirow[t]{5}{*}{ Education } & School Certificate & 8 & $3.8 \%$ \\
\hline & OND/NCE & 26 & $12.3 \%$ \\
\hline & HND/BSC & 109 & $51.4 \%$ \\
\hline & Professional & 13 & $6.1 \%$ \\
\hline & Others & 6 & $2.8 \%$ \\
\hline \multirow[t]{5}{*}{ Work Experience } & $1-3$ years & 51 & $24.1 \%$ \\
\hline & $4-5$ years & 59 & $27.8 \%$ \\
\hline & $6-9$ years & 52 & $24.5 \%$ \\
\hline & 10 years and above & 49 & $23.1 \%$ \\
\hline & Missing Item & 1 & $0.5 \%$ \\
\hline
\end{tabular}

$(\mathrm{n}=212)$

Source: Field Survey, 2017

From the table, it is clear that there are more men than women that partook in the study, 122 men $(57.5 \%)$ and 90 were women (42.5\%). A total of $120(56.6 \%)$ respondents are wedded. The chunks of the participants were between 31 and 40 years of age, and $51.4 \%$ had a first degree, $23.6 \%$ had a postgraduate degree and $6.1 \%$ had professional qualifications. In terms of working experience, $76.8 \%$ had between one and nine years.

Table 2 Descriptive Statistics and Pearson Correlation Coefficients

\begin{tabular}{lrccccccc}
\hline Variables & Mean & $\begin{array}{c}\text { Standard } \\
\text { Deviation }\end{array}$ & 1 & 2 & 3 & 4 & 5 & 6 \\
\hline Employee's Motivation & 25.59 & 5.592 & - & & & & & \\
Pay dissatisfaction & 3.97 & 2.015 & .424 & - & & & & \\
Equitably underpaid & 3.12 & 1.681 & .406 & .643 & - & & & \\
Underpaid & 3.50 & 1.802 & .442 & .715 & .675 & - & & \\
Overtime underpaid & 2.80 & 2.354 & .492 & .369 & .392 & .405 & - & \\
Inadequate review of salary & 3.28 & 1.766 & .486 & .644 & .564 & .669 & .434 & - \\
Salary review not based on procedures & 3.18 & 1.757 & .456 & .521 & .632 & .506 & .425 & .545 \\
\hline
\end{tabular}

Correlation is significant at 0.05 level (1-tailed), $p<0.05$

Source: Field Survey, 2017 
Descriptive statistics are taking the nature of arithmetic means, that is, the average of what the respondents are saying in terms of their conformity to the statements and their perception about the issue. The computed Standard deviations for participants for overall employees' motivation as the dependent variable has 25.59 as weighted average and 5.592 standard deviation as presented in Table 2 above and this is to confirm that there may be a great dispersion from what the respondents are saying. Questionnaire assessment on compensation management items under Table 2 displays averages for pay dissatisfaction, equitably underpaid, underpaid, overtime underpaid, inadequate review of salary and salary review not based on procedures ranged from a low 2.80 to a high 3.97. The pay dissatisfaction, equitably underpaid, underpaid, overtime underpaid, inadequate review of salary and salary review not based on procedures are treated as the independent variable which is compensation.

This is an indication of poor motivation but value of overtime underpaid is the lowest which indicates that this is an area that workers are demoralised and discontented. Moreover, Table 2 portrays that the workers are inspired and happy beside equitably underpaid, salary review not based on procedures, inadequate review of salary, underpaid and pay dissatisfaction items but they are least motivated by the item overtime payment is underpaid. This is in line with Herzberg's (1966) two factor theory where he discussed hygiene elements.

Pearson's product moment correlation coefficient was run to establish association that exists between overall employees' motivation as dependent variable and items of compensation management as the independent variables. However, to explain the relation between the various items of reward administration and workers' enthusiasm, items that were correlated are presented under Table 3.

Table 3 Coefficients between compensation management and employees' motivation.

\begin{tabular}{lc}
\hline Variables & $\begin{array}{c}\text { Employees' } \\
\text { Motivation }\end{array}$ \\
\hline Pay dissatisfaction & .424 \\
Equitably underpaid & .406 \\
Underpaid & .442 \\
Overtime underpaid & .492 \\
Inadequate review of salary & .486 \\
Salary review not based on procedures & .456 \\
\hline \multicolumn{2}{c}{ Correlation is significant at 0.05 level (1-tailed), p<0.05 } \\
\multicolumn{2}{c}{ Source: Field Survey, 2017 }
\end{tabular}

All the variables above are significant but very low and the most significant one is overtime underpaid with .492 followed by inadequate review of salary with significance level of .486 .

Table 3 reveals that statistically, weak association exists amongst all items of compensation management and total motivation. The correlations between overall employees' motivation and compensation management items show statistically at the 5\% level: overall employees' motivation with overtime underpaid $(\mathrm{r}=.492, \mathrm{p}<.05)$, overall employees' motivation with inadequate review of salary $(\mathrm{r}=.486, \mathrm{p}<.05)$, overall employees' motivation with salary review not based on procedures $(\mathrm{r}=.456, \mathrm{p}<.05)$, overall employees' motivation with underpaid 
$(\mathrm{r}=.442, \mathrm{p}<.05)$, overall employees' motivation with pay dissatisfaction $(\mathrm{r}=.424, \mathrm{p}<.05)$, and overall employees' motivation with equitably underpaid $(\mathrm{r}=.406, \mathrm{p}<.05)$. All these depict overall employee drive and all items under compensation management are significantly related but weak throughout. The result of this study corroborates the previous work done on compensation and employees' motivation by (Chiu, Luk, \& Tang, 2002; Danish and Usman, 2010; Herpen, Praag, and Cools, 2005; Mawoli and Babandako, 2011; Solomon, Hashim, Mehdi and Ajagbe, 2012)

Table 4 Pearson correlation between reward administration and employees' motivation

\begin{tabular}{lccccc}
\hline & $\mathrm{N}$ & Mean & Std.D & $\mathrm{R}$ & $\mathrm{P}$ \\
\hline Reward administration & 208 & 3.9667 & 2.00334 & & \\
Employees motivation & 208 & 5.7524 & 1.40433 & .648 & .000 \\
\hline Con
\end{tabular}

Correlation is significant at the 0.05 level. $\mathrm{p}<0.05$, reward administration and the staff motivation is significantly associated.

Source: Field Survey, 2017

Table 4 shows the relationship between reward administration and the staff motivation in an insurance firm in Nigeria. As indicated in table 4, correlation between reward administration and the employees' drive is 0.648 . The p-value is 0.000 and is lower than .05 with correlation coefficient $\mathrm{R}=0.648$. The correlation between reward administration and workers' motivation of the insurance firm in Nigeria is very strong because the correlation coefficient is 0.648 or $64.8 \%$. This entails that a linear relationship exists amidst the variables which discloses a positive relationship. In other words, compensation management contributes significantly to motivation of staff in insurance industry in Nigeria. Still association between compensation management and employees' motivation is not very strong.

This study investigates association amid pay dissatisfaction, equitably underpaid, underpaid, over-time underpaid, inadequate review of salary, and salary review not based on procedures, which are compensation management items related to employees' motivation. The result is in accordance with the objectives of this study. Pearson product moment correlation coefficient was computed deliberately to determine relationship between various compensation management items and overall employees' motivation, the result found was quite revealing and interesting. Although the relationship is not strong enough, it still shows that employees' are not highly motivated in the insurance industry in Nigeria. The correlation between overall employee motivation and payment for overtime has the highest significant relationship of 0.492 or $49.2 \%$ to the lowest value of 0.406 between overall employees' motivation and equitable pay with other people in similar jobs. The weak values among the compensation management items are due to the fact that salary review and implementation in the Nigerian insurance industry is not often carried out by managements nor is it done periodically. The low employee motivation in the insurance industry in Nigeria is a common feature because of the disparity in payments within the industry and this is as a result of the ownership structure, that is, most insurance companies are owned by private individuals. One of the revelations of this study is that there is an outcry through the responses of the participants that there is pay dissatisfaction, equitably underpaid when compared with their counterparts in similar industry. It was also revealed that there is underpaid, overtime underpaid, inadequate review of salary and salary review not based on procedures which culminated to not being motivated 
The result of this study is of immense value for both people at managerial level and decision- makers. Managers should make workers' salaries commensurate with tasks being carried out. Secondly, the management should ensure that the disparity between what the employee receives and what other people in similar jobs are receiving is not wide. Thirdly, the rate being paid for overtime should be improved upon to motivate employees when required to work extra hours. Fourthly, the salary review should be done fairly and not favour some employees at the expense of others. Lastly, the salary review should follow a laid down procedure and should be done periodically especially when the firm is making progress. If all these factors are considered in the insurance industry in Nigeria, there will be a reduction in labour intent, absenteeism, strikes and industrial disputes, and it will also lead to high productivity levels, high revenue generation and improved organisational performance.

For further studies, focus may be shifted to other industrial sectors of the economy like manufacturing industry, construction industry, and oil industry and could also include focusing on combining organisations within the same sector, for example, banking, and insurance and stockbrokerage industries.

The study outcomes have far reaching inferences for human resource administrators in Nigeria's insurance division. Specifically, inferences on employee motivation. The analysis revealed weak relationship amidst reward administration and worker motivation in the industry. HR practitioners are encouraged to improve on their compensation management strategies to be able to hire talented skilled people and retain them.

The research work further employed bivariate analytical method to test the relationship between the variables with the use of the Statistical Package for Social Sciences (SPSS) version 22.0 where the relationship is of a quantitative nature, and measured the prediction of the value of a variable based on the value of two variables, simple regression technique is applied (Mann \& Lacke, 2010; Pallant, 2011).

In presenting the estimated model coefficients, the equation obtained from the linear function regression result is given as:

$$
\mathrm{Y}=\mathrm{a}_{0}+\beta_{1} \mathrm{x}_{1}
$$

Where $\mathrm{a}_{0}=$ constant;

$\beta=$ coefficient of independent variable

$\mathrm{X}_{1}=$ Compensation (independent variable)

$\mathrm{Y}=$ Motivation (dependent variable)

$$
\mathrm{Y}=3.075 \mathrm{a}+0.359 \mathrm{x}_{1}
$$

A simple regression was run to predict motivation of employees (dependent variable) from compensation (independent variable). Table 1 indicates that the independent variables yielded a coefficient of determination $\left(\mathrm{R}^{2}\right)$ of $0 . .329$ accounting for $32.9 \%$ of the proportion of variation in dependent variable that is explained by the independent variable. Table 2, then, shows that the analysis of variance for the simple regression data produced F-ratio value of 102.178 which is significant at 0.05 (.i.e. $F(1,210)=102.178$, $\mathrm{p}<0.05)$. In table 3 , the independent variable (i.e Compensation) contributed positively and statistically to motivation of employees at a low relationship. The result is in consistence with empirical findings of Idris et al. (2017) and Mardiyanti et al. (2018) who noted that compensation management acts as an antidote to the motivation of an employee that invariably transforms the performance of the employees' which also translates to positive organizational outcome. 
Compensation Management and Employees' Motivation in the Insurance Sector: Evidence from Nigeria 43

Model Summary

\begin{tabular}{ccccc}
\hline Model & $\mathrm{R}$ & R Square & Adjusted R Square & $\begin{array}{c}\text { Std. Error } \\
\text { of the Estimate }\end{array}$ \\
\hline 1 & $.574^{\mathrm{a}}$ & .329 & .326 & .76005 \\
\hline \multicolumn{3}{c}{$\begin{array}{l}\text { Predictors: (Constant), Com_Mgt } \\
\text { Dependent Variable: Motivation }\end{array}$} \\
\end{tabular}

ANOVA $^{\mathrm{a}}$

\begin{tabular}{lccccc}
\hline \multicolumn{1}{c}{ Model } & Sum of Squares & df & Mean Square & F & Sig. \\
\hline Regression & 59.025 & 1 & 59.025 & 102.178 & $.000^{\mathrm{b}}$ \\
1 Residual & 120.155 & 208 & .578 & & \\
Total & 179.180 & 209 & & \\
\hline \multicolumn{5}{c}{ Dependent Variable: Motivation } \\
Predictors: (Constant), Com_Mgt
\end{tabular}

Coefficients $^{\mathrm{a}}$

\begin{tabular}{lccccc}
\hline \multirow{2}{*}{ Model } & \multicolumn{2}{c}{$\begin{array}{c}\text { Unstandardized } \\
\text { Coefficients }\end{array}$} & $\begin{array}{c}\text { Standardized } \\
\text { Coefficients }\end{array}$ & T & Sig \\
\cline { 2 - 4 } & $\mathrm{B}$ & Std. Error & Beta & & \\
\hline (Constant) & 3.075 & .129 & & 23.869 & .000 \\
1 Com_Mgt & .359 & .036 & .574 & 10.108 & .000 \\
\hline
\end{tabular}

a. Dependent Variable: Motivation

\section{CONCLUSION}

This study explores the impact of reward administration on employees' motivation. The analysis revealed weak link amid reward administration and workers' motivation in insurance industry in Nigeria, but overtime payment has shown low mean value and an insignificant relationship to overall employee motivation. The weak or insignificant relationship between compensation management and employee motivation can be improved upon by management through reviewing the pay packages of the employees, making sure that there is equitable pay structure in line with similar industries, and that overtime payment should be adequately worked on. Finally, the review of salary should be done in a fair manner, periodically and procedurally.

Though the contribution of this study is significant to academia and practitioners of HR, there are drawbacks that open up opportunities for future research. Firstly, this study covers only an industry from the insurance sector in Nigeria. Subsequently, researchers can endeavour to extend the study to cover other sectors in Nigeria. 


\section{REFERENCES}

Adams, J.S. (1963). Toward an understanding of inequity. Journal of Abnormal and Social Psychology, 67, $422-436$. Adeoye, A.O. (2001). Contemporary issues in human resources management and organisational behaviour. Lagos: Pumark Publishers.

Adeoye, A.O. (2014). An assessment of compensation management and motivation on organisational performance in the Insurance Industry in Nigeria. An Unpublished Doctoral Dissertation, University of KwaZulu-Natal, Durban, South Africa.

Adeoye, A.O. \& Fields, Z. (2014). Compensation management and employee job satisfaction: a case of Nigeria. India Journal of Social Sciences, 41 (3), 345-352.

Aguinis, H., Joo, H. \& Gottfredson, R.K. (2013). What monetary rewards can and cannot do: how to show employees the money. Business Horizon, 56, 241-249. http://dx.doi.org/10.1016/j.bushor.2012.11.007

Agwu, M.O. (2013). Impact of fair reward system on employee's job performance in Nigerian Agip Oil Company Limited, Port Harcourt. British Journal of Education, Society and Behavioural Science, 3 (1), 47-64.

Ahlstrom, D. \& Bruton, G.D. (2010). International management: Strategy and culture in the emerging world. Hampshire: South-Western, Cengage Learning, EMEA.

Ali, N.A.M. \& Panatik, S.A. (2015). Work values and job satisfaction among academician in public and private university. Jurnal Kemanusiaan, 24 (2), 43-58

Altindis, S. (2011). Job motivation and organisational commitment among the health professionals: a questionnaire survey. African Journal of Business Management, 5 (21), 8601-8609. http://dx.doi.org/10.5897/ AJBM11.1086

Al-Shaiba, A.S. \& Koç, M. (2017). Role of human resources function in successful organizational transformations for efficiency improvement. European Journal of Multidisciplinary Studies, 2 (7), 273-280.

Armstrong, M. (2003). A handbook of human resource management practice. 9th edition. Aberystwyth: Cambrian Printers.

Asika, N. (2008). Research methodology: Process approach. Lagos: Mukugamu Brothers.

Baruch, Y. \& Hotlom, B.C. (2008). Survey response rate levels and trends in organisational research. Human Relations,61,1139-1160. http://dx.doi.org/10.1177/0018726708094863

Brislin, R.W., Kabgting, F., Macnab, B., Zukies, B. \& Worthley, R. (2005). Evolving perceptions of Japanese workplace motivation. International Journal of Cross Cultural Management, 5 (1), 87-103. http://dx.doi.org/10.1177/1470595805050829

Brown, M. (2001). Unequal pay, unequal responses? Pay referents and their implications for pay level satisfaction. Journal of Management Studies, 38 (6), 879-896. http://dx.doi.org/10.1111/1467-6486.00263

Byron, K. (2005). A meta-analytic review of work-family conflicts and its antecedents. Journal of Vocational Behaviour, 67 (2), 169-198. http://dx.doi.org/10.1016/j.jvb.2004.08.009

Calder, B.J. \& Staw, B.M. (1975). The self-perception of intrinsic and extrinsic motivation. Journal of Personnel and Social Psychology, 31, 599-605.

Chartered Institute of Personnel and Development, (2005). Reward Management. Survey report. London: CIPD.

Chartered Institute of Personnel and Development, (2006). International reward and recognition guide. London: CIPD.

Chiu, R.K., Luk, V.W. \& Tang, T.L. (2002). Retaining and motivating employees: compensation preferences in Hong Kong and China, Personnel Review, 31 (4), 402-431. http://dx.doi.org/10.1108/00483480210430346

Danish, R.Q. \& Usman, A. (2010). Impact of reward and recognition on job satisfaction and motivation: An empirical study from Pakistan. International Journal of Business and Management, 5 (2), 159-167.

Darma, P.S. \& Supriyanto A.S. (2017). The effect of compensation on satisfaction and employees performance. Management and Economic Journal, 1 (1), 69-78. http://dx.doi.org/10.18860/mecj.v1.1.4524

Dessler, G. (2008). Human resource management. Upper Saddle River: Prentice Hall.

Egan, M., Yang, B. \& Bartlett, K.R. (2004). The effects of organisational learning culture and job satisfaction on motivation to transfer learning and turnover intention. Human Resources Development Quarterly, 15 (3), 279 300. http://dx.do.org/10.1002/hrdq.1104

Gagne, M. \& Deci, E.L. (2005). Self-determination theory and work motivation. Journal of Organisational Behaviour, 26 (4), 331-362. http://dx.doi.org/10.1002/job.322

George, D. \& Mallery, P. (2003). SPSS for Windows step by step: A simple guide and reference. 11.0 update 4th edition. Boston: Allyn \& Bacon.

Hackett, T.J. \& McDermott, D.G. (1999). Integrating Compensation Strategies: A holistic approach to compensation design. Compensation and Benefit Review, 31 (5), 36-43. http://dx.doi.org/10.1177/088636879903100506

Heinemann, R.L. (2002). Strategic Reward Management: Design, Implementation, and Evaluation. Greenwich, CT: Information Age Publishers. 
Heneman III, H.G., Judge, T.A. \& Heinemann, R.L. (2000). Staffing organisations. New York: McGraw Hill/Irwin. Herpen, M.V., Praag, M.V. \& Cools, K. (2005). The effects of performance measurement and compensation on motivation: an empirical study. De Economica, 153 (3), 303-329. http://dx.doi.org/10.1007/s10645-005-1990-z

Herzberg, F. (1966). Work and the nature of man. Cleveland: World Publishing Company.

Herzberg, F., Mausner, B. \& Snyderman, B. (1959). The motivation to work. New York: Wiley.

Hyondong, K. (2006). Strategic impacts of compensation system on organisational outcomes: An empirical study of the conceptualisations of fit and flexibility in the compensation design. (Unpublished doctoral dissertation). Graduate School of the Ohio State University, USA.

Idris, M.H., Hamzah, D., Sudirman, I. \& Hamid, N. (2017). The relevance of financial and non-financial compensation on professionalism and lecturers performance: Evidence from Makassar Private Universities (Indonesia). Journal of Asian Development, 3 (2), 162-180.

Ivancevich, J.M. (2004). Human resource management. 9th edition. New York: McGraw Hill

James, P. \& Kim, I. (2018). CEO compensation in the U.S.: Are CEOs underpaid or overpaid? Accounting and Finance Research, 7 (3), 78-101. http://dx.doi.org/10.5430/afr,v7n3p78

Johnson, C.R. (2005). Employee motivation: A comparison of tipped and non-tipped hourly restaurant employees. (Unpublished Masters dissertation). Rosen College of Hospitality Management, University of Central Florida, Orlando, Florida, USA.

Kalshoven, K. \& Boon, C.T. (2015). Ethical leadership, employee well-being, and helping: the moderating role of human resource management. Journal of Personnel Psychology, 11 (1), 60-68.

Kelly, P. (2009). International business and management. Hampshire: South-Western, Cengage Learning, EMEA.

Kersley, B.A. \& Forth, J. (2005). Inside the workplace: First findings from 2004 Workplace Employment Relations Survey (WERS 2004). London: Economic and Social Research Council.

Khan, R.I., Aslam, H.D. \& Lodhi, I. (2011). Compensation management: A strategic conduit towards achieving employee retention and job satisfaction in banking sector of Pakistan. International Journal of Human Resource Studies, 1 (1), 89-97.

Khoreva, V. (2012). Gender inequality, gender pay gap, and pay inequity: perceptions and reactions in Finnish society and workplace,' Unpublished Doctoral Dissertation, Hanken School of Economics, Department of Management and Organisation.

Kreitner, R. \& Kinicki, A. (1998). Organisational behaviour. 4th edition. New York: McGraw Hill/Irwin.

Kumar, D., Hossain, M.Z. \& Nasrin, M.S. (2015). Impact of non-financial rewards on employee motivation. Asian Accounting and Auditing Advancement, 5 (1), 18 -25.

Kuranchie-Mensah, E.B. \& Amponsah-Tawiah, K. (2016). Employee motivation and work performance: A comparative study of mining companies in Ghana. Journal of Industrial Engineering and Management, 9 (2), 255-309. http://dx.doi.org/10.3926/jiem.1530

Leete, L. (2000). Wage equity and employees motivation in non-profit and for-profit organisations. Journal of Economic Behaviour and Organisations, 43 (4), 423-446. http://dx.doi.org/10.1016/S0167-2681(00)00129-3

Lin, H.F. (2007). Effects of extrinsic and intrinsic motivation on employee knowledge sharing intentions. Journal of Information Sciences, 33 (2), 135-149. http://dx.doi.org/10.1177/0165551506068174

Mabaso, C.M. \& Dlamini, B.I. (2017). Impact of compensation and benefits on job satisfaction. Research Journal of Business and Management, 11 (2), 80-90. http://dx.doi.org/10.3923/rjbm.2017.80.90

Mahaney, C.R. \& Lederer, A.L. (2006). The effect of intrinsic and extrinsic rewards for developers on information systems project success. Production Management Journal, 37 (4), $42-54$.

Mann, P.S. \& Lacke, C.J. (2010). Introductory statistics. $7^{\text {th }}$ edn. USA: John Wiley \& Sons, Inc.

Mardiyanti, O.A., Utami, H.N. \& Prasetya, A. (2018). The effect of financial compensation and non-financial compensation on employees' performance through job satisfaction as an intervening variable: Study on permanent employees' of PT Citra Perdana Kendedes in Malang, East Java. Jurnal Administrasi Bisnis, 62 (1), 135-144.

Mawoli, M.A. \& Babandako, A.Y. (2011). An evaluation of staff motivation, dissatisfaction and job performance in an academic setting," Australian Journal of Business and Management Resources, 1 (9), 1-13.

Maynard, D.C., Joseph, T.A. \& Maynard, A.M. (2006). Underemployment, job attitudes and turnover intentions. Journal of Organisational Behaviour, 27 (4), 509-536. http://dx.doi.org/10.1002/job.389

Mckee-Ryan, F.M. \& Harvey, J. (2011). I have a job, but----- A review of underemployment. Journal of Management, 37 (4), 962-996.

Meta, M., Alib, I. \& Alic, J. (2015). Do monetary reward and job satisfaction influence employee performance: evidence from Malaysia. Journal of Business and Social Sciences, 3 (11), 184-200.

Mitchell, T.R. (1982). Motivation: New direction for theory, research, and practice. Academy of Management Review, 7 (1), 80-88.

Milkovich, G.T. \& Newman, JM. (1999), Compensation. 6th edition. New York: McGraw Hill. 
Mottaz, J.C. (1985). The relative importance of intrinsic and extrinsic rewards as determinants of work satisfaction," The Sociological Quarterly, 26 (3), 365-385. http://dx.doi.org/10.1111/j.1533-85251985.tb00233.x

Muijs, D. (2011). Doing quantitative research in education with SPSS. $2^{\text {nd }}$ edition. London: Sage Publications.

Mujataba, B. \& Shuaib, S. (2010). An equitable total rewards approach to pay for performance management.' Journal of Management Policy and Practice, 11 (4), 111-121.

Nazim-ud-Din, M. (2013). HR practices in insurance companies: A case study of Bangladesh. Abasyn Journal of Social Sciences, 16 (2), 77-90.

Nell, I.A. (2015). Preaching from the pews: a case study in vulnerable theological leadership. Verbum et Ecclesia 36 (1), Art \#1376, 9 pages. http://dx.doi.org/10.4102/ve.v36i/o1376. (Accessed 5 May 2016).

Nickels, W.G., McHugh, J.M. \& McHugh, S.M. (1999), Understanding business. 5th edition. New York: McGraw Hill/Irwin.

Nzyoka, C.M. \& Orwa, B.H. (2016). The relationship between total compensation and employee performance in the insurance industry: Case of Mayfair Insurance Company Limited. Psychology and Behavioral Sciences, 5 (1), 20-36. http://dx.doi.org/10.11648/j.pbs.20160501.14

Nikonova, O.V., Uspenskaya, T.N., Nazarova, U.A. \& Voikina, E.A. (2018). Features of remuneration of workers of social protection organizations in the Russian Federation: By the example of the City of Moscow. The Turkish Online Journal of Design Art and Communication. TOJDAC, September Special Edition; 2086-2093. http://dx.doi.org/10.7456/1080SSE/280

Oburu, L.N. \& Atambo, W.N. (2016). The effect of compensation on employee performance of micro-finance institutions: A case of Wakenya Pamoja Sacco, Kisii County, Kenya. Imperial Journal of Interdisciplinary Research, 2 (6), 103-126.

Olusadum, N.J. \& Anulika, N.T. (2018). Impact of motivation on employee performance: A study of Alvan Ikoku Federal College of Education. Journal of Management and Strategy, 9 (1), 53-65. http://dx.doi.org/10.5430/ jms.v9n1p53

Osterloh, M. (2005). Human resources management and knowledge creation. Forthcoming in: I. Nonaka, \& K. Ichijo (Eds.): Handbook of Knowledge Creation, Oxford University Press.

Osterloh, M. \& Frey, B.S. (2000). Motivation, knowledge transfer, and organisation forms. Organisational Science, 11 (5), 538-550. http://dx.doi.org/10.1287/orsc.11.5.538.15204

Osterloh, M., Frost, J. \& Frey, B.S. (2002). The dynamics of motivation in new organisational forms. International Journal of Economy of Business, 9 (1), 61-77. http://dx.doi.org/10.1080/13571510110102976

Pallant, J. (2011). SPSS survival manual: step-by-step guide to data analysis using SPSS. $4^{\text {th }}$ edn. Australia: Allen \& Unwin.

Parke, C.A. (2013). Essential first steps to data analysis: Scenario-based examples using SPSS. Los Angeles: SAGE.

Pepra-Mensah, J., Adjei, L.N. \& Agyei, A. (2017). Effect of compensation on basic school teachers' job satisfaction in the northern zone: The case of Ghana. Global Journal of Management and Business Research, G. Interdisciplinary, 17 (3), 50-59.

Purcell, J., Kinnie, N. \& Hutchinson, S. (2003). Understanding the people and performance link: Unlocking the black box. London: Chartered Institute of Personnel and Development.

Ramlall, S. (2004). A review of employee motivation theories and their implications for employee retention within organisations. Journal America Academy of Business, Cambridge, 5 (1\&2), 52-63.

Resurrection, P.F. (2012). Performance management and compensation as drivers of organisational competitiveness: The Philippine perspective. International Journal of Business and Social Sciences, 3 (21), 20-30.

Rotea, C.S., Logofatu, M. \& Ploscaru, C.C. (2018). Quantitative model for assessing the impact of reward system elements on hospital efficiency. International Journal of Academic Research in Business and Social Sciences, 8 (8), 231-241. http://dx.doi.org/10.6007/JJARBSS/v8-18/4461

Rynes, S.L., Gerhart, B. \& Minette, K.A. (2004). The importance of pay in employees' motivation: Discrepancies between what people say and what they do. Human Resource Management, 43 (4), 381-394. http://dx.doi.org/ 10.1002/hrm.20031

Saunders, M.N., Lewis, P. \& Thornhill, A. (2013). Research methods for business students. $5^{\text {th }}$ edition. London: Pearson Education.

Seiler, S., Lent, B., Pinkowska, M. \& Pinazza, M. (2012). An integrated model of factors influencing project managers' motivation-findings from a Swiss survey. International Journal of Production Management, 30 (1), 60-72.

Serhan, C., Achy, E.A. \& Nicolas, E. (2018). Public sector employees' motivation: Causes and effects. People: International Journal of Social Sciences, 4 (2), 49-55. http://dx.doi.org/10.20319/pijss.2018.42.4955 
Solomon, O., Hashim, H.N., Mehdi, Z.T. \& Ajagbe, A.M. (2012). Employee motivation and organisational performance in Multinational Companies: A study of Cadbury Nigeria Plc. International Journal of Resources in Management and Technology, 2 (3), 303-312.

Swartz, G.E. (2006). Safety in the supervisor's salary review. Professional Safety, Sept, 54-58.

Sweeney, P.D. (1990). Distributive justice and pay satisfaction: A field test of an equity theory prediction. Journal of Business and Psychology, 4 (3), 329-341.

Tang, T.L. \& Chiu, R.K. (2004). Income, money ethic, pay satisfaction, commitment, and unethical behaviour: Is the love of money root of all evil for Hong Kong employees?, Journal of Business Ethics, 46, 13-30.

Tang, T.L., Luna-Arocas, R., Sutarso, T. \& Tang, D.S. (2004). Does the love of money moderate and mediate the income-pay satisfaction relationship?. Journal of Managerial Psychology, 19 (2), 111-135. http://dx.doi.org/ $10.1108 / 02683940410526091$

Terre Blanche, M., Durrheim, K. \& Painter, D. (2006). Research in practice: Applied methods for the Social Sciences. Cape Town: University of Cape Town Press.

Tsai, C. (2005). Reward Incentive Compensation and Organisational Performance: Evidence from the semiconductor industry. Performance and Reward Conference, Manchester U.K., April

Uwizeye, H. \& Muryungi, P. (2017). Influence of compensation practices on employee performance of tea companies in Rwanda: A case study of Rwanda Mountain Tea. European Journal of Business and Social Sciences, 6 (6), 160-167.

Van der Merwe, S.P. (2009). Determinants of family employee work performance and compensation in family business. South African Journal of Business Management, 40 (1), 51-63.

Walker, C.O., Greene, B.A. \& Mansell, R.A. (2006). Identification with academics, intrinsic/extrinsic motivation, and self-efficacy as predictors of cognitive engagement. Leadership and Individual Differences, 16 (1), 1-12. http://dx.doi.org/10.1016/j.lindif.2005.06.004

Whitehead, O. \& Phippen, A. (2015). An investigation into the ideas and effects of zero-hour contracts within the United Kingdom. Journal of Research Studies in Business and Management, 1 (1), 189-209.

Willis-Shattuck, M., Bidwell, P., Thomas, S., Wyness, L., Blaauw, D. \& Ditlopo, P. (2008). Motivation and retention of health workers in developing countries: A systematic review. BMC Health Service Resources, 8, 247.

Woźniak, J. (2017). Some factors hindering acceptance of three gamification solutions in motivation systems in small and medium enterprises. Management Dynamics in the Knowledge Economy, 5 (4), 663-680. http://dx.doi.org/10.25019/MDKE/5.4.11

Yao, Y.H., Locke, E.A. \& Jamal, M. (2018). On a combined theory of pay level satisfaction. Journal of Organizational Behavior, 39 (4), 448-461. http://dx.doi.org/10.1002/job.2243

\section{UPRAVLJANJE NAKNADAMA I MOTIVACIJA ZAPOSLENIH U SEKTORU OSIGURANJA: SLUČAJ NIGERIJE}

Nadoknada je jedan od ključnih alata koje organizacije primenjuju da bi privukle, zaposlile $i$ zadržale kompetentne zaposlene koji će se strateški uključiti u viziju, zadatke i ciljeve kompanije. Zadržavanje sposobih zaposlenih unitar kompanije je ključno za njen napredak i poboljšanje opšteg poslovanja. Kadar koji je dobro motivisan će se truditi da osigura da se ostvari konkurentna prednost organizacije $i$ da se ostvari prednost nad konkurencijom. Cilj ovog rada je da istraži vezu između upravljanja naknadama i motivacije zaposlenih u sektoru osiguranja u Nigeriji. Istraživanje je koristilo ne-eksperimentalnu shemu koristeći upitnike kao istrumetne merenja za prikupljanje informacija. Podeljeno je 250 upitnika, sakupljeno 213, od kojih je 212 (84.4\%) bilo upotrebljivo. Korišćenjem Pearsonovog koeficijenta korelacije proizvoda, otkriveno je da postoji veza između raspodela nagrada $i$ motivacije zaposlenih, ali da je ona slaba. Otkriveno je da u nigerijskoj industriji osiguranja, upravljanje naknadama ima minimalni uticaj na entuzijazam radnika. Stoga se preporučuje da paket naknada zaposlenima u industriji osiguranja u Nigeriji treba da dobije prioritet tako što će se periodično vršiti korekcija zarada i usklađivati sa drugim industrijama u finansijskom sektoru Nigerije.

Ključne reči: upravljanje naknadama, zaposleni, industrija osiguranja, motivacija, Nigerija 